\title{
Glances from Afar: Paul Valéry and Henri Poincaré
}

\author{
Claudio Bartocci
}

Published online: 22 May 2013

(C) Centro P.RI.ST.EM, Università Commerciale Luigi Bocconi 2013

\begin{abstract}
The French poet and essayist Paul Valéry was fascinated by Henri Poincaré, who he never met but often observed. His description of Poincaré is an unusual and captivating portrait of the great mathematician.
\end{abstract}

\section{Keywords Paul Valéry · Henri Poincaré}

From 1887 until the year of his death, Henri Poincaré resided at number 63 of Rue Claude Bernard, just behind the École Normale Supérieure. From 1891 until 1899, Paul Valéry lived just a few hundred metres away, at number 13 of Rue Gay-Lussac. Valéry caught sight of the celebrated scientist rather frequently, and described him thus:

[his] shoulders ... were hunched, the beard short, his dress serious and well-made, a cockade. His gaze, through the trembling crystal of his glasses, was empty and fixed. He walked along, vaguely pulled along by the weight of his forehead bent over. The tread of his uncertain steps seemed to be at the mercy of his being's most concealed power. The finger of this illustrious passer-by brushed distractedly along the walls that moved opposite to the direction in which he moved, unconsciously drawings arcs that belied the profound presence of a geometric brain; and the body of his mind moved as it could in this world, which is only one world among many possible worlds [6, p. 711].

But the two men never exchanged a word, and the idea sketched by Valéry, in a letter of January 1896 to André

C. Bartocci $(\square)$

Dipartimento di Matematica, Università di Genova,

via Dodecaneso 35, 16146 Genoa, Italy

e-mail: bartocci@dima.unige.it
Gide, of making a 'portrait' of Poincaré for La Nouvelle Revue, was never carried out. Valéry had written, Poincaré est difficile à faire sans le connaître (Poincaré is difficult to do without knowing him) [2, p. 374]. His admiration for and curiosity about Poincaré could only be indulged at a distance: 'This morning, 20 May (1900), at the funeral of Ravaisson-Mollien, I observed at length the head of Poincaré' [8, III (1990), p. 337].

Valéry-who after the intellectual palingenesis of the nuit de Gênes (the existential crisis he experienced during a heavy storm on the night of 4 October 1892) attempted to create a new language ex novo, and at the same time a world view-discovered Poincaré in 1894, while reading the article 'Sur la nature du raisonnement mathématique' [3]; he was thunderstruck. In the so-called Carnet de Londres [10, p. 114], the notation 'reasoning by recurrence' immediately precedes, like a kind of short circuit, a statement that would become, with a slight modification, the incipit of the Soirée avec Monsieur Teste: La bêtise ne sera jamais mon fort (Stupidity will never be my strong point) [9, p. 1; Eng. trans. p. 21]. Two years later, in the notebook entitled "Self-Book", Valéry put Poincaré first in the short list—just six names-of 'living and famous men' who had earned the young writer's admiration [7, I (1973), p. 204].

Valéry, as shown by the frequent references scattered throughout the Cahiers, was an assiduous and careful reader of the papers Poincaré published in the Revue de métaphysique et de morale. The articles 'L'espace et la géométrie' $[4]^{1}$ and 'La mesure du temps' $[5]^{2}$ would leave

\footnotetext{
${ }^{1}$ A passage from this article is quoted in [Valéry Cahiers 1894-1914, I (1987), p. 215].

2 See the editors' comments in [Valéry, Cahiers 1894-1914, IX (2003), p. 284 ("note to p. 230").
} 
very evident traces in Valéry's works, from his 1895 Introduction à la méthode de Léonard de Vinci to the 1923 dialogue Eupalinos ou l'architecte.

In a text that dates to 1920 , the 'poet of impassive rigor of mind' (as Italo Calvino defined him [1, p. 65]) returned in memory to his occasional meetings with the 'illustrious passer-by' of more than two decades earlier, drawing two extraordinary micro-portraits (one of which we have already quoted), which shed light on the contrast between the ordinariness of Poincare physical appearance and his intellectual grandeur:

See this little man, grey and poorly garbed? ... He is one of the greatest men in the world. Look at that two-bit Panama hat: that frayed straw conceals an intellectual world. This body, full of aches and pains, dressed half in alpaca, half in coarse cotton, is a precision instrument. And this fisherman with his fishing line is a fisher of thoughts that each day bring to shore a quantity of fish that are stranger, more diverse, more vibrant ... that all those than the poor fisherman of $A$ Thousand and One Nights netted in an enchanted sea [7, II (1974), p. 1271].

Translated from the Italian by Kim Williams

\section{References}

1. Calvino, I.: Six Memos for the Next Millennium. The Charles Eliot Norton Lectures 1985-86. Vintage Books, New York (1993)

2. Gide, A., Valéry, P.: Correspondance 1890-1942, P. Fawcett, ed. Gallimard, Paris (2009)

3. Poincaré, H.: "Sur la nature du raisonnement mathématique". Revue de métaphysique et de morale 2, 371-384 (1894). Rpt. in H. Poincaré, La science et l'hypothèse. Flammarion, Paris (1902) (English trans. "On the Nature of Mathematical Reasoning", chap. I, pp. 1-16 in Science and Hypothesis, W. J. Greenstreet, trans. London: Walter Scott Publishing; 1905)
4. Poincaré, H. "L’Espace et la Géométrie", Revue de Métaphysique et de Morale 3, 631-646 (1895) (English trans. "Space and Geometry", chap. IV, pp. 51-71 in Science and Hypothesis, W. J. Greenstreet, trans. Walter Scott Publishing, London; 1905)

5. Poincaré, H.: "La mesure du temps", Revue de métaphysique et de morale 6, 1-13 (1898) (English trans. "The Measure of Time", pp. 222-234 in The Foundations of Science, George Bruce Halsted, trans. Science Press, New York; 1913)

6. Valéry, P.: "Passage de Verlaine" (1921). Variété, Études littéraires, Euvres, vol. I, J. Hytier, ed. Gallimard, Paris (1957)

7. Valéry, P.: Cahiers, 2 vols. J. Robinson-Valéry, ed. Gallimard, Paris (1973-1974)

8. Valéry, P.: Cahiers 1894-1914. 12 vols. Celeyrette-Pietri, N., Robinson-Valéry, J., et al. (eds.) Gallimard, Paris (1987-2012)

9. Valéry, P.: La Soirée avec Monsieur Teste (1896). Gallimard, Paris (Paris) (English trans. An evening with Mr. Teste. Ronald Davis, trans. Ronald Davis, Paris; 1925)

10. Valéry, P.: 1894. Carnet inédit "Carnet de Londres", F. de Lussy, ed. Gallimard/Bibliothèque Nationale de France, Paris (2005)

\section{Author Biography}

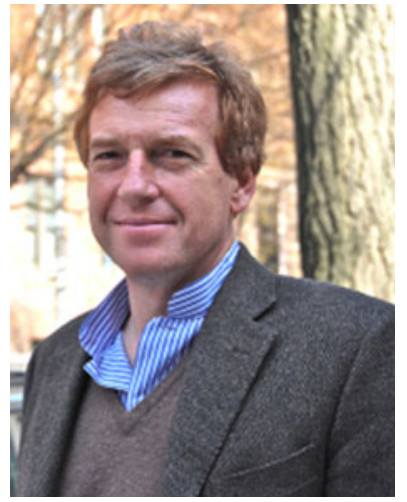

Claudio Bartocci is associate professor of mathematics at the Univesity of Genoa. His research interests are focused on the following topics: algebraic geometry and mathematical physics, history of the mathematical thought in the nineteenth and twentieth centuries, philosophy of mathematics. His recent books include: Una piramide di problemi (Raffaello Cortina, Milan, 2012); New Trends in Geometry: Their Role in the Natural and Life Sciences (coedited with L. Boi and C. Sinigaglia, Imperial College Press, London, 2011); Fourier-Mukai and Nahm transforms in geometry and mathematical physics (coauthored with U. Bruzzo and D. Hernández Ruipérez, Birkhäuser, Boston, 2009); Mathematical Lifes (coedited with R. Betti, A. Guerraggio, R. Lucchetti, Springer, Berlin, Heidelberg, 2010). He is the coeditor, with P. Odifreddi, of La matematica (Torino, Einaudi, 4 volumes, 2007-2011). 